\title{
UJI AKTIVITAS ANTIOKSIDAN BUAH SEMANGKA (Citrullus lanatus) DENGAN METODE FRAP
}

\author{
Masdiana Tahir, Anda Cahya H., Harti Widiastuti \\ Fakultas Farmasi Universitas Muslim Indonesia, Makassar \\ Email : masdiana.tahir@umi.ac.id.
}

\begin{abstract}
Have been conducted a research about antioxidant activity assay at watermelon (Citrullus lanatus) using FRAP method. Watermelon is known contains vitamin $A, B, C$, and lycopene. The aim of research were to determine the antioxidant activity relationship between watermelon juice and vitamin $C$ with FRAP method using ascorbic acid as a comparative standard measure by UV-Vis spectrophotometer at a wavelength of $692 \mathrm{~nm}$. The research result was obtained the antioxidant capacity on the watermelon red meat juice 0,1329 mg AAE/g.
\end{abstract}

Keywords : Antioxidant, FRAP method,Watermelon (Citrullus lanatus).

\section{PENDAHULUAN}

Keanekaragaman tumbuhan di Indonesia diperkirakan tidak kurang dari 25.000 jenis. Kekayaan ini telah banyak dimanfaatkan bagi kehidupan, salah satunya sebagai tumbuhan obat. Hutan Indonesia memiliki jenis tumbuhan obat tidak kurang dari 9606 jenis dan baru sebagian kecil yang diteliti secara ilmiah. Banyak potensi tumbuhan obat yang belum diketahui terutama dari segi aktivitas biologisnya. Salah satu potensi dari tumbuhan obat tersebut adalah sebagai antioksidan. Tumbuhan yang memiliki potensi sebagai antioksidan banyak dijumpai dilingkungan sekitar kita seperti sayur-sayuran (brokoli, wortel, tomat, bayam, mentimun, kubis), buah-buahan (anggur, alpukat, jeruk, semangka,apel), rempahrempah (jahe, kunyit, cengkeh, lengkuas) dan tumbuhan lainnya. Antioksidan yang terkandung dalam tumbuhan berupa vitamin $\mathrm{C}$, vitamin $\mathrm{E}$, karoten dan golongan fenol ${ }^{1-2}$.

Antioksidan adalah senyawa yang dapat menetralisir radikal bebas dengan cara menyumbangkan elektronnya pada senyawa radikal bebas. Senyawa antioksidan dapat mencegah kerusakan yang ditimbulkan oleh radikal bebas terhadap sel normal, protein, dan lemak. Penggunaan senyawa antioksidan saat ini semakin meluas 
seiring dengan semakin besarnya pemahaman masyarakat tentang peranannya dalam menghambat penyakit degeneratif seperti penyakit jantung, arteriosclerosis, kanker, serta gejala penuaan ${ }^{3}$.

Semangka diketahui mengandung zat-zat tertentu yang dapat membunuh sel-sel kanker. Profesor Masatoshi Yamazaki dari Universitas Tokyo memaparkan hasil temuannya yaitu "Semangka, pisang, dan rumput laut mengandung zat-zat yang dapat menstimulir phagocyte". Phagocyte adalah suatu sel darah merah yang mampu melindungi sistem darah dari infeksi dengan cara menyerap mikroba untuk mematikan sel-sel penyebab penyakit kanker. Manfaat semangka yang lain adalah dapat berfungsi sebagai diuretik karena kandungan kalori semangka yang sangat rendah. Semangka juga mengandung pigmen karotenoid jenis flavonoid yang menyebabkan warna merah atau kuning. Flavonoid dapat pula berperan sebagai anti alergi. Selain itu, buah semangka jugamengandung vitamin, mineral dan lain-lain ${ }^{4}$.

Di dalam buah semangka terdapat kandungan zat-zat yang sangat berguna bagi kesehatan tubuh manusia. Manfaat dari kandungan buah semangka antara lain melindungi jantung, memperlancar pengeluaran urine, dan menjaga kesehatan kulit. Fungsinya tidak sekadar penghilang dahaga, tapi juga sebagai antioksidan yang baik. Kadar antioksidan yang tinggi pada semangka dapat diandalkan sebagai penetral radikal bebas dan mengurangi kerusakan sel dalam tubuh ${ }^{5}$.

Pengukuran aktivitas antioksidan dapat dilakukan dengan beberapa metode diantaranya DPPH (2,2-difenil-1-pikrilhidrazil),

FRAP (ferric reducing antioxidant power) dan CUPRAC (cupricion reducing antioxidant capacity) ${ }^{6}$.

Pada penelitian ini di gunakan metode FRAP, karena metodenya murah, cepat, dan reagen yang digunakan cukup sederhana serta tidak menggunakan alat khusus untuk menghitung total antioksidan. Metode FRAP adalah metode yang digunakan untuk menguji antioksidan dalam tumbuh-tumbuhan. Metode FRAP digunakan untuk mengukur kemampuan antioksidan dalam mereduksi $\mathrm{Fe}^{+3}$ menjadi $\mathrm{Fe}^{+2} 7$.

Berdasarkan uraian diatas, maka dilakukan penelitian yang bertujuan untuk mengetahui aktivitas antioksidan buah semangka (ctrullus lanatus.) dengan menggunakan 
metode FRAP (Ferric reducing antioxidant power).

\section{METODE PENELITIAN}

\section{A. Alat dan Bahan yang Digunakan}

Alat yang digunakan dalam penelitian ini adalah alat-alat gelas, juicer, timbangan analitik (Acis AD-600H), mikropipet (Memmert), sentrifuge, spektrofotometer UV-Visible (Apel $P D$ 302UV.Bahan yang digunakan adalah aquades, asam trikloroasetat $\left(\mathrm{CCl}_{3} \cdot \mathrm{CO}_{2} \mathrm{H}\right) \quad 10 \%$, sampel buah semangka (citrullus lanatus), buffer fosfat0,2 $\mathrm{M} \mathrm{pH}$ 6,6, feri klorida $\left(\mathrm{FeCl}_{3}\right) \quad 0,1 \%$, kaliumferri sianida $\left(\mathrm{K}_{3} \mathrm{Fe}(\mathrm{CN})_{6}\right) \quad 1 \%$, natrium hidroksida $(\mathrm{NaOH})$,kalium dihidrogen fosfat $\left(\mathrm{KH}_{2} \mathrm{PO}_{4}\right)$ dan asam askorbat.

\section{Prosedur Penelitian}

\section{Penyiapan Sampel}

Sampel buah semangka diperoleh dari supermarket/pasar swalayan di kota makassar, Propinsi Sulawesi Selatan. Buah semangka yang diperoleh, terlebih dahulu di kupas kulitnya kemudian dibersihkan dari bijinya, lalu daging buah semangka di potong kecil-kecil. Daging buah ditimbang $100 \mathrm{~g}$ kemudian ditambahkan larutan asam oksalat 0,4\% $100 \mathrm{ml}$ dan di blender lalu disaring. Kemudian diambil $5 \mathrm{ml}$ dan disentrifuge selama 10 menit dengan kecepatan 2000 rpm. Kemudian diambil supernatannya sebanyak $1 \mathrm{ml}$ dan diencerkan dengan larutan asam oksalat $0,4 \%$ ke dalam labu ukur $10 \mathrm{ml}$ sampai batas tanda ${ }^{8}$.

\section{Uji Aktivitas Antioksidan dengan Metode FRAP \\ Penentuan panjang gelombang maksimum}

Untuk menentukan panjang gelombang maksimum standar asam askorbat di running pada panjang gelombang 650-750 nm. Larutan standar asam askorbat $1000 \mathrm{ppm}$ di pipet sebanyak 0,4 $\mathrm{ml}$ kemudian di tempatkan pada labu ukur $10 \mathrm{ml}$ yang berbeda dan diencerkan dengan asam okslat $1 \%$ hingga batas $10 \mathrm{ml}$ dan di homogenkan. Konsentrasi larutan standar asam askorbat 40 ppm di pipet $1 \mathrm{ml}$ ke dalam tabung sentrifuge dicampur dengan buffer fosfat $(1 \mathrm{~mL}$, $0,2 \mathrm{M}, \mathrm{pH}$ 6,6) dan $1 \mathrm{~mL}$ kalium ferisianida $1 \%$, campuran diinkubasi pada suhu $50^{\circ} \mathrm{C}$ selama 20 menit. Setelah selesai diinkubasi, ditambahkan $1 \mathrm{~mL}$ asam trikloroasetat dan dihomogenkan selama 10 menit, selanjutnya di sentrifuge pada 3000 rpm selama 10 menit. Diambil lapisan atas dari larutan tersebut sebanyak $1 \mathrm{ml}$ kemudian ditambahkan dengan 1 
$\mathrm{mL}$ aquades dan $0,5 \mathrm{~mL} \mathrm{FeCl}_{3}$ 0,1\%. Absorbansi diukur pada ג maks 650750 dengan spektro UV-Vis.

\section{Pengukuran larutan blangko}

Di pipet $1 \mathrm{ml}$ asam oksalat $1 \%$ kemudian di pipet $1 \mathrm{ml}$ larutan dapar fosfat (2 M pH 6,6) dan larutan $\mathrm{K}_{3} \mathrm{Fe}(\mathrm{CN})_{6} \quad 1 \%$ sebanyak $1 \mathrm{ml}$, diinkubasi pada suhu $50^{\circ} \mathrm{C}$ selama 20 menit. Kemudian ditambahkan larutan TCA $10 \%$ sebanyak $1 \mathrm{ml}$ lalu disentrifuge selama 10 menit dengan kecepatan 3000 rpm. Supernatan dipipet $1 \mathrm{ml}$ ke dalam tabung reaksi, ditambahkan $1 \mathrm{ml}$ aquades dan 0,5 $\mathrm{ml}$ $\mathrm{FeCl}_{3} 0,1 \%$ lalu dibaca pada panjang gelombang $692 \mathrm{~nm}$ dengan spektrofotometer UV-Vis.

\section{Pembuatan kurva baku asam askorbat}

Larutan stok 1000 ppm dibuat dengan melarutkan $25 \mathrm{mg}$ asam askorbat dilarutkan dengan asam oksalat $1 \%$ lalu diencerkan hingga batas labu ukur $25 \mathrm{ml}$. Selanjutnya dari larutan stok 1000 ppm diambil masingmasing sebanyak $0,4,0,5,0,6,0,7$ dan 0,8 $\mathrm{ml}$ dan ditempatkan pada labu ukur berbeda dan diencerkan dengan asam oksalat $1 \%$ hingga $10 \mathrm{~mL}$ dan dihomogenkan. Konsentrasi larutan standar asam askorbat yang terbentuk berturut-turut 40 ppm, 50 ppm, 60 ppm, 70 ppm, 80 ppm. Kemudian diambil supernatannya sebanyak $1 \mathrm{~mL}$ selanjutnya dicampur dengan $1 \mathrm{~mL}$ buffer fosfat $(0,2 \mathrm{M}, \mathrm{pH} 6,6)$ dan $1 \mathrm{~mL}$ kalium ferisianida1\%, campuran diinkubasi pada suhu $50^{\circ} \mathrm{C}$ selama 20 menit. Setelah selesai diinkubasi, ditambahkan $1 \mathrm{~mL}$ asam trikloroasetat dan dihomogenkan selama 10 menit, selanjutnya disentrifuge pada 3000 rpm selama 10 menit. Diambil lapisan atas dari larutan tersebut sebanyak $1 \mathrm{ml}$ kemudian ditambahkan dengan 1 $\mathrm{mL}$ aquades dan $0,5 \mathrm{~mL} \mathrm{FeCl}_{3} 0,1 \%$. Absorbansi diukur pada ג maks 692 $\mathrm{nm}$ dengan spektrofotometer UV-Vis.

\section{Penentuan absorbansi sampel}

Diambil larutan sampel $1 \mathrm{ml}$ dan ditambahkan buffer fosfat $1 \mathrm{~m}(0,2 \mathrm{M}$ $\mathrm{pH} 6,6)$ dan $1 \mathrm{ml}$ kalium ferisianida1\%, lalu diinkubasi pada suhu $50^{\circ} \mathrm{C}$ selama 20 menit. Setelah selesai diinkubasi, ditambahkan $1 \mathrm{ml}$ asam trikloroasetat dan dihomogenkan selama $\quad 10 \quad$ menit,selanjutnya disentrifuge pada 3000 rpm selama 10 menit. Diambil lapisan atas dari larutan tersebut sebanyak $1 \mathrm{ml}$ kemudian ditambahkan dengan 1 $\mathrm{mL}$ aquades dan $0,5 \mathrm{~mL} \mathrm{FeCl}_{3} 0,1 \%$. Absorbansi diukur pada ג maks 692 $\mathrm{nm}$ dengan spektrofotometer UVVis $^{8}$. 


\section{HASIL PENELITIAN}

Berdasarkan penelitian yang telah dilakukan maka diperoleh hasil sebagai berikut :

Tabel 1. Hasil pengukuran absorbansi dan nilai aktivitas antioksidan buah semangka (Citrullus lanatus) dengan metode FRAP.

\begin{tabular}{ccccc}
\hline Sampel & Replikasi & $\begin{array}{c}\text { Absorbansi } \lambda \text { maks } \\
(\mathbf{6 9 2} \mathbf{~ n m )}\end{array}$ & $\begin{array}{c}\text { Aktivitas } \\
\text { Antioksidan } \\
\text { (mgAAE/g sampel) }\end{array}$ & $\begin{array}{c}\text { Rata-rata } \\
\text { mgAAE/g } \\
\text { sampel }\end{array}$ \\
\hline Daging & 1 & 0,667 & 0,1363 & \\
buah & 2 & 0,614 & 0,1245 & 0,1329 \\
semangka & 3 & 0,682 & 0,1381 & 0,1329 \\
\hline
\end{tabular}

\section{PEMBAHASAN}

Antioksidan adalah senyawa kimia yang dapat menyumbangkan satu atau lebih elektron kepada radikal bebas, sehingga reaksi radikal bebas tersebut dapat terhambat.

Manfaat dari kandungan buah semangka antara lain melindungi jantung, memperlancar pengeluaran urine, dan menjaga kesehatan kulit. Semangka yang masuk dalam keluarga Cucurbitaceae ini, fungsinya tak sekadar penghilang dahaga, tapi juga sebagai antioksidan yang baik.

Buah berbentuk bulat ini juga mengandung vitamin $\mathrm{C}$ dan $\mathrm{A}$ dengan jumlah besar, dengan kadar antioksidan yang tinggi, semangka dapat diandalkan sebagai penetral radikal bebas dan mengurangi kerusakan sel dalam tubuh.

Kelebihan metode FRAP ini yaitu metodenya yang murah, cepat, dan reagen yang digunakan cukup sederhana serta tidak menggunakan alat khusus untuk menghitung total antioksidan. Metode FRAP digunakan untuk mengukur kemampuan antioksidan dalam mereduksi $\mathrm{Fe}^{3+}$ menjadi $\mathrm{Fe}^{2+}$ dengan peningkatan nilai absorbansi menunjukkan besarnya aktivitas antioksidan dari sampel yang diuji antioksidannya.

Terbentuknya warna hijau menyebabkan kenaikan pada nilai absorbansi sampel. Makin warna hijau yang terbentuk pada sampel makin tinggi nilai absoransinya. Ini akan menunjukan aktivitas antioksidan yang terkandung dalam tanaman semangka. Sampel dengan daya reduksi tinggi merupakan donor elektron yang bagus yang memiliki kemampuan untuk menghentikan reaksi berantai radikal dengan cara merubah radikal bebas menjadi produk yang lebih stabil. Akitivitas antioksidan dari reduktan berdasarkan pada pemcahan rantai 
radikal akibat pemberian atom hidrogen. Penelitian ini dilakukan dengan tujuan untuk mengetahui kandungan antioksidan pada daging buah semangka (Citrullus lanatus) dengan menggunakan metode FRAP.

Sebelum penelitian dilakukan, terlebih dahulu dilakukan pengamatan dan pengambilan sampel buah semangka yang berada di Provinsi Sulawesi Selatan. Buah semangka yang harus diambil yaitu buah semangka yang memiliki kualitas yang baik,yakni buah semangka yang segar dan matang.

Pada penentuan panjang gelombang maksimum uji aktivitas antiksidan buah semangka, diperoleh panjang gelombang maksimum 692 nm. Sampel diukur pada panjang gelombang maksimum, karena memiliki keuntungan yaitu pada panjang gelombang maksimum kepekaannya juga maksimum, daya serap relatif konstan dan bentuk kurva absorbansi cenderung lurus sehingga pada kondisi tersebut hukum LambertBeer akan terpenuhi. Perbedaan panjang gelombang yang diperoleh dapat dipengaruhi oleh perbedaan sensitivitas instrumen, pelarut yang digunakan dan cara pengerjaan individu sehingga besarnya perbedaan panjang gelombang maksimum hasil pengamatan biasanya bergeser antara 0 sampai $4 \mathrm{~nm}$.

Pengujian aktivitas antioksidan metode FRAP, buah semangka dibersihkan terlebih dahulu dan daging buah ditimbang $100 \mathrm{~g}$ kemudian ditambahkan larutan asam oksalat 0,4\% $100 \mathrm{ml}$ dan di blender lalu disaring. Kemudian diambil $5 \mathrm{ml}$ dan disentrifuge selama 10 menit dengan kecepatan 2000 rpm. Kemudian diambil supernatannya sebanyak $1 \mathrm{ml}$ dan diencerkan dengan larutan asam oksalat $0,4 \%$ ke dalam labu ukur $10 \mathrm{ml}$ sampai batas tanda. Selanjutnya, diambil $1 \mathrm{ml}$ dan ditambahkan dengan buffer fosfat (0.2 M, pH 6.6) kemudian tambahkan $1 \mathrm{~mL}$ larutan kalium ferrisianida $1 \%$ yang akan mereduksi ion $\mathrm{Fe}^{3+}$ dalam larutan menjadi ion $\mathrm{Fe}^{2+}$. Reaksi ini terjadi pada kondisi $\mathrm{pH}$ 6,6. Reaksinya adalah sebagai berikut :

$$
\begin{aligned}
& \mathrm{K}_{3}\left[\mathrm{Fe}(\mathrm{CN})_{6}\right] \longrightarrow \mathrm{K}_{4}\left[\mathrm{Fe}(\mathrm{CN})_{6}\right] \\
& \mathrm{Fe}^{3+}+\mathrm{e}^{-} \longrightarrow \mathrm{Fe}^{2+}
\end{aligned}
$$

Setelah itu,diinkubasi pada suhu $50^{\circ} \mathrm{C}$ selama 20 menit. Kemudian sebanyak $1 \mathrm{~mL}$ asam trikloroasetat $10 \%$ ditambahkan ke dalam larutan agar kompleks kalium ferosianida mengendap dan dapat dipisahkan. Proses pemisahannya dibantu dengan sentrifuge selama 10 menit. Setelah disentrifuge diambil $1 \mathrm{ml}$ 
bagian atas supernatannya.

Ditambahkan $1 \mathrm{~mL}$ aquades dan 0,5 $\mathrm{mL}$ larutan $\mathrm{FeCl}_{3} \quad 0,1 \%$ untuk membentuk kompleks berwarna hijau sampai biru (Pearl's Prussian Blue) sehingga dapat dibaca pada spektrofotometri pada panjang gelombang $692 \mathrm{~nm}$.

Pada penelitian ini diperoleh persamaan regresi $y=0,008 x+0,156$, $r=0,997$ berdasarkan data tersebut dapat disimpulkan bahwa terdapat hubungan linear antara konsentrasi dengan serapan sesuai dengan hukum lambert-beart.

Dari hasil penelitian ini diperoleh aktivitas antioksidan dari daging buah semangka merah yaitu dari replikasi pertama absorbansi sampel yaitu 0,667 dengan aktivitas antioksidan sebesar 0,1363mg AAE/gr sampel. Replikasi ke dua absorbansi sampel yaitu 0,614 dengan aktivitas antioksidan sebesar $0,1245 \mathrm{mg}$ AAE/grsampel. Replikasi ke tiga absorbansi sampel yaitu 0,682 dengan aktivitas antioksidan sebesar 0,1381 mg AAE/gr sampel. Dengan nilai ratarata 3 replikasi dari sampel daging buah semangka merah yaitu sebesar 0,1329mg AAE/gr sampel.

\section{KESIMPULAN}

Dari hasil penelitian dapat disimpulkan bahwa nilai aktivitas antioksidan pada daging buah semangka dengan metode FRAP ratarata sebesar $0,1329 \mathrm{mg} A A E / g r$ sampel setara dengan asam askorbat.

\section{DAFTAR PUSTAKA}

1. Hernani dan Rahardjo $M$. Tanaman Berkhasiat Antioksidan. Penebar Swadaya : Jakarta, 2006.

2. Puji PA. Uji Aktivitas Antioksidan Ekstrak Air dan Ekstrak Metanol Beberapa Varian Buah Kenitu (Chysophyllum cainito L.) dari daerah Jember. FMIPA: Universitas Jember. 2007; $13: 45$ 50

3. Zuhud. Antioksidan Nabati Ramuan dan Aplikasi. Penebar Swadaya: Jakarta. 2011.

4. Prajnanta F. Agribisnis Semangka Non-Biji. Penebar Swadaya: Jakarta. 2003.

5. Rochmatika DL, Kusumaastuti $H$, Setyaningrum DG, Muslihah IN. Analisis Kadar Antioksidan pada masker wajah berbahan dasar lapisan putih kulit semangka (Citrullus Vulgris Schard). Fakultas MIPA Universitas Negeri. Yogyakarta : Yogyakarta, 2012.

6. Widyastuti dan Niken. Pengukuran Aktivitas Antioksidan dengan METODE CUPRAC, DPPH, DAN FRAP serta korelasinya dengan fenol dan flavanoid pada enam tanaman (skripsi). Institut Pertanian Bogor : Bogor, 2010.

7. Szőllösi R dan Varga I.Total antioxidant Power in some Species of Labiate (Adaptation of FRAP method). J Biologica Szegediensis 2002; 46: 125-127. 
Uji Aktivitas Antioksidan Buah Semangka (itrullus lanatus) Dengan Metode FRAP

8. Yen GC, dan Chen HY.

Antimutagenicity. J Agric Food Antioxidants Activityof Various Chem 1993 ; 43: 383-386.

Tea Extracts in Relation to Their 